\title{
The Program of the Association of College and Reference Libraries
}

\section{A Report by the Policies Committee}

Soon after its organization, the Association of College and Reference Libraries $\mathcal{O}$ established a Policies Committee headed by Dr. Carl M. White. This committee for the past two years has devoted much study to the Association's organization, scope, and growth. It has also sought and benefited from the advice of numerous interested members. The final report of the committee, published herewith, was presented to the Association's Board of Directors at Boston. In the belief that this document is of fundamental importance in guiding the future development of the Association, the board voted for its publication in College and Research Libraries.

The object of the A.C.R.L. as stated in its constitution is to promote library service and librarianship in college and research libraries. Accordingly, it is the policy of the Association to "direct and carry on a program of activities to advance (a) the standards of library service, in the broadest sense, in these kinds of libraries, and (b) the continued professional and scholarly growth of those engaged in the work of these libraries." The purpose of this report is to outline briefly a program which will make this statement of aim and policy more definite.

\section{Build an effective organization.}

Experience with the College and Reference Section had shown by 1936 that something was lacking. It was concluded that college and research libraries needed a stronger organization-one that would promote more control, unity, and selfdirection in the activities with which they are concerned. The Association of College and Reference Libraries came into existence in answer to this need. It is an expression of a desire to accomplish through united effort the objectives stated in the A.L.A. Constitution and in the Constitution and By-laws of the A.C.R.L. Subsequent experience may reveal ways in which the form of organization can be adapted better to the ends served by the A.C.R.L. But though this means change, the aim should remain the same-to have an organization that is as effective as possible.

The present organization is a division of the A.L.A. For conducting its work the division receives 20 per cent of the dues paid to the A.L.A. by each personal member (except class $\mathrm{A}$ members and A.L.A. life memberships in force before July I, 1939). It has complete autonomy over and responsibility for the conduct of its own affairs and the expenditure of allotted funds subject to the restrictions imposed by the A.L.A. Constitution and Bylaws. These restrictions are liberal, being aimed at the coordination of all interests and activities of the A.L.A. Thus A.L.A. committees dealing wholly or chiefly with the activities of the A.C.R.L. are appointed by the Executive Board of the 
A.L.A., but the Board of Directors of the A.C.R.L. is given opportunity to present nominations. Similarly in the case of important A.L.A. boards and committees, which concern to a considerable extent the chief activities of the A.C.R.L., the Board of Directors may either (I) submit two or more nominations for each board or committee (if not more than two other groups are concerned with the work of the committee or if the A.L.A. By-laws definitely provide for such nominations) or (2) nominate an advisory subcommittee to the A.L.A. committee (in case the work of the A.L.A. board or committee conrerns more than three groups).

Within the A.C.R.L. any group of twenty or more members may organize a separate section upon securing the approval of the Board of Directors. At present there are six sections representing respectively agricultural libraries, college libraries, junior college libraries, reference librarians, libraries of teacher training institutions, and university libraries. There is a point, difficult to define, beyond which further subdivision into sections will be harmful rather than beneficial to the A.C.R.L. Probably few additional applications for separate sections are to be expected, but it would seem to be sound policy for the Board of Directors henceforth to ask any who present such applications to show that the requested action will not carry the Association past the danger mark of decentralization.

2. Make the present affiliation with the American Library Association a fruitful relationship.

Now that the A.C.R.L. has been voted its independence, two courses are open to us. We may make the present affiliation with A.L.A. a formal but somewhat empty relationship, or we may make it considerably more meaningful. The intent of the scheme of organization which took shape as a result of the Third Activities Committee report was to provide at once a maximum of autonomy in the management of affairs of the different divisions and a maximum of coordination in the work of the A.L.A. as a whole. The two principles of autonomy and coordination face in opposite directions, but neither can be sacrificed without costs which American librarians need not and should not pay. Changes in the pattern of activities within the A.L.A. are already evident as a result of reorganization. There will be other changes, necessary changes. Nevertheless, American libraries have much in common; and freedom, though a heady potion, should not make us insensible of the mutual advantages of a common front in dealing with our common problems. The basic framework of our present organization seems to make ample provision for effective coordination. How fruitful it will be in actual practice, however, will depend very materially upon American library leadership - its capacity for teamwork and the limits of its horizon.

The spirit of professional comradeship thus envisaged has been expressed by one university librarian as follows: "When a problem is identified as belonging primarily to college and reference libraries the A.C.R.L. should accept chief responsibility for studying and finding a solution for it. When a problem concerns the A.C.R.L. but belongs primarily to an organization established to cope with it, the A.C.R.L., though leaving the chief responsibility with the other organization, should always be willing to join with that organization in its efforts to solve that problem." In general, the A.C.R.L. 
should leave problems relating to functional or other special activities of college and reference libraries to special divisions, boards, or committees of the A.L.A. which are set up to deal with such activities. There is nothing rigid about this natural division of labor, and the emphasis is intended to be positive. In other words, any worthwhile contribution should be welcome regardless of the source.

\section{Provide for continuity of leadership.}

The governing body of the A.C.R.L.the Board of Directors-is composed of a president, vice president, retiring president, secretary, treasurer, three directors-atlarge, six directors from the respective sections, and the chairmen of the sections as ex officio members. The advantage that results from this scheme of control is the responsiveness of the government of the Association to the will of the membership. But there are disadvantages. The president and the chairmen of sections, who hold the key positions of leadership, are elected for one year only, although the new constitution makes the vice president the president-elect. Moreover, the very concentration of authority and responsibility in the hands of the Board of Directors means that it must handle considerable routine business in the course of the year and at the same time supply the imagination and the initiative in planning the activities of the Association. Finally, the size of the board and the infrequency of meetings slow down the pace of its work.

The basic need is more continuity in the leadership. An ancillary need is a division of labor which will disengage at least one person from routine business and push him prominently into the foreground of leadership. There are at least three ways of attaining these ends. One method would be to have at A.L.A. Headquarters a consultant, who, whatever the formal relation to the A.C.R.L., would be capable of making for himself a prominent place in all councils and activities relating to college and research libraries. This is the most favored course to pursue, but it is not open to us at present.

The A.L.A. Constitution empowers the Board of Directors to appoint, if it so desires, "a special board or committee which is to be recognized as the body to consider general or specific matters relating to the general activities of the group." Such a special board or committee could hold office as long, and perform such functions, as the Board of Directors would specify in creating it. A third course would be to elect an executive secretary whose relation to the A.C.R.L. would be analogous to that of the Executive Secretary of the A.L.A. Such an office seems to have been contemplated by the Third Activities Committee, the final report of which reads in part as follows: "Each division is to be organized ... with an executive secretary elected for not less than three years . .." This course seems to offer the most promising course for immediate action. Unless funds are found, no salary ${ }^{1}$ could be offered and hence the responsibilities of the position would have to be carried in addition to other work. However, the opportunities for statesmanly service and achievement would be sufficiently challenging to entitle the post to serious consideration by the person invited to accept it. It is recommended that the position be created and

1 A suggestion has come to the committee that the Board of Directors of the A.C.R.L. might consider Board of Directors of the A.C.R.L. might consider the possibility of paying an honorarium of - Say- $\$ 200$ a year in addition to clerical assistance. This would
of course mean less of a sacrifice on the part of one who might care to accept the responsibility. 
that the appointment be made for a period of five years. Favorable action will entail an amendment to the By-laws of the A.C.R.L., which at present make no mention of such position. The President would continue to be the chief administrative officer of the Association and the Secretary the officer who follows and keeps a record of its transactions. The Executive Secretary would be an executive officer who would carry out the instructions of the President and Board of Directors. In actual practice, it is supposed that the President and Board of Directors, of which the Executive Secretary would be a member, would develop a program of activities, part of which cannot be accomplished in a single year. The chief responsibility of the Executive Secretary would be the management, under the the President and Board of Directors, of this program of activities.

A second means of providing more continuity in leadership is to make the role of the directors from the sections a more responsible one. No changes in constitution or by-laws are necessary; it is largely a matter of making full use of our present organization. The sections can make little or considerable use of these directors, as they see fit. Since the directors are elected for a period of three years and since they participate in the work of their respective sections and in the councils of the governing board of the A.C.R.L., they are in a singularly advantageous position to keep the sections abreast of developments in which they are or should be interested, to steer sectional programs toward long-range objectives, and to help weld the A.C.R.L. into a cohesive unit. ${ }^{2}$

2 The committee has been invited to consider the desirability of a planning committee for each section. It believes that if such a scheme for planning is followed, care should be taken not to disperse effort. If the Board of Directors concludes that time
4. Cultivate mutual understanding between librarians and their colleagues in learned societies and other professional associations.

It was emphasized above that all American librarians should continue to work side by side in close unity. The principle enunciated there of maintaining a common front in dealing with common problems should be applied to problems of higher education, as well as to problems of librarianship in the narrower sense of the term. There are a variety of ways in which college and research librarians can unite their efforts with colleagues in learned and professional bodies in dealing with matters of mutual interest. One way would be to send representatives of the Association of College and Reference Libraries to regular meetings of those bodies whose interests are the most closely linked with libraries and to designated meetings of other bodies. A second method, not necessarily separate from the first, would be to encourage the use of librarians as speakers on programs where topics having a bearing on libraries are to be discussed. One librarian advocates the policy of "holding some of our meetings, perhaps alternate meetings, at colleges and universities in conjunction with such organizations as the Association of American Colleges, the Association of American Universities, land-grant colleges associations, the Association of American University Professors. This seems to me one of the most important factors in making closer contact with college administrators and faculties. This

should be devoted to planning which it is itself not prepared to give and wishes to have a committee assume this task, it could appropriately be assigned to the sectional directors collaborating with the President or the proposed executive secretary. It is worth emphasizing that more use can be made of these sectional directors. 
should be to the good of all concerned." The Policies Committee prefers to leave specific steps to the Board of Directors, but favors action which will bring college and research librarians into closer association with their colleagues in learned societies and other professional organizations within the academic world. With particular reference to joint meetings, as proposed above, the implications have not been fully studied, but the committee questions whether arranging two sets of programs for all sections each year, independently of the work of other academic organizations, represents the most productive use of time.

5. Enlist career members of college, university, and research library staffs.

No criticism of the old College and Reference Section was more disquieting than the fact that it reached only a fraction of those eligible for membership. When the A.C.R.L. came into existence a membership campaign was launched. The present membership of approximately 2000 against 192 for the College and Reference Section in 1937 indicates the progress that has been made. ${ }^{3}$ In the belief that a clear declaration of purpose is an aid to organized effort, the committee has given some thought as to what the enlistment goal should be. Our conclusion is that membership officers of the A.C.R.L. and the A.L.A. should, with the aid of local libraries, seek to enlist all career members of the staff of the libraries that are represented. In the last analysis the term 'career member' cannot be defined except in terms of the intentions of the

3 The approximate figure given for present membership was secured at the Boston meeting. In August, I 940, the membership stood at 1003. The rapid increase is due to an intensive campaign that has increase is due to an intensive campaign that has
been waged in recent months. In all, some been waged in recent months. In all, some 3200
letters have been sent out to aid in enlistment. librarian concerned, and this limitation is a disadvantage; but it has the merit of focusing attention upon that large and fairly stable group of librarians who are now working and who, barring accidents of health, losses to other professions, and the unpredictable inroads of matrimony, will continue to work in the college and research libraries of the United States and Canada.

Perhaps the chief value of a rather clearly defined membership goal would be the more active use that could be made of representatives of the local library staff by the proper membership officers. "Every career member of the staff a member of the A.C.R.L."-here is something definite to aim at. The task implied is one that can be delegated at long range with a few carefully stated directions and one which many of our staff members will doubtless readily assist in handling. It is hardly necessary to add that assistance should be sought from the rank and file of the staff. No healthy membership campaign can be sponsored by the chief librarian, although there is of course no reason why his or her attitude should not be known.

\section{Plan stimulating meetings.}

A conscious distinction needs to be drawn between two purposes of the annual and midwinter meetings of the A.C.R.L. One purpose is to transact business. The other is to present a program that will further the professional growth of the membership. These are not the only purposes served by the meetings of the Association, but they are probably the most important ones. The Policies Committee is convinced that the second purpose is entitled to more consideration than it has received heretofore. There are several 
reasons for this conviction. One has to do with enlistment. Not much lasting good will be done if large numbers of librarians join the A.C.R.L. and are encouraged to attend its meetings if the benefits to the individual do not measure up to expectations. These benefits do not have to be interpreted in terms that are too narrow. As an example, perhaps an extreme one, a competent, well-delivered address on an interesting phase of the history of Boston would probably be as welcome to the circulation assistant who comes to the Hub city for the first time as the same amount of time spent in discussing methods of handling fines. His colleague in the catalog department would probably welcome an introduction to members of the Boston Public Library catalog staff as readily as an introduction to forms used at the University of $\mathrm{A}-$ in a cost study of cataloging.

The second reason is that the encouragement of individual growth through wellplanned meetings is a proper aim of professional association. Many who have watched the library profession from within the walls of library schools believe that there is now too much dependence on these schools. At the meetings, the same as on the job, the thing that has seemed to matter unreasonably much is getting things done. The professional development of the rank and file has too often not been consciously recognized as a proper purpose of a meeting; or if recognized, something has gone wrong with the execution of the idea. We have concentrated too much on activities of special interest to chief librarians and other administrators. Prior to its recent reorganization, the American Library Association was possibly better organized than at present to deal swiftly and efficiently with such activities. The greater democracy of the present organization is thus purchased with a price, and the cost will be dear indeed unless the opportunity thus created of benefiting the rank and file is effectively utilized.

The relation of the A.C.R.L. to the Association of Research Libraries should be mentioned in this connection. Some have raised a question whether there is a place both for it and for the University Section of the A.C.R.L. The Association of Research Libraries is an organization composed entirely of institutional members. The viewpoint is that of the library administrator; no meetings are held for the benefit of the staffs of the libraries represented. On the other hand, the University Section of the A.C.R.L. offers no opportunity for the intimate discussion of common institutional problems such as that provided by the Association of Research Libraries. It is true that a problem is created by virtue of the fact that the A.L.A. as well as the Association of $\mathrm{Re}$ search Libraries offers institutional membership. But there is no reason why the work of the University Section of the A.C.R.L. and that of the Association of Research Libraries cannot be complementary. ${ }^{4}$

Before turning to another topic the easily neglected axiom ought to be stressed that stimulating meetings are the result of careful program planning-not of

\footnotetext{
4 A comment on this part of the report from one university librarian, a regular attendant of meetings of the Association of Research Libraries, is worth quoting. The Association of Research Libraries, he says, "is concerned with research from the standpoint of the institution rather than from the soind of the intitution rather than from the standpoint of the library. It certainly could no replace the University Section of the A.C.R.L. For example, the University Section of the A.C.R.I. ought to consider the question of service to the great number of undergraduates in our big universities. This subject is not in the province of the A.R.L. The training of staff members in the large university libraries is another point. The A.R.L. is not interested in research questions so much from the standpoint of the staff as from the standpoint of the university."
} 
formal organization. Separate divisions and sections are useful means of promoting projects of interest to the separate groups represented, but this separateness can easily disperse effective effort when it comes to planning stimulating programs, particularly if they come twice a year. All officers of the Association are urged to bear in mind this fact and to cooperate with each other in developing strong programs of wide popular appeal. One suggestion that has reached the committee is to have the President of the A.C.R.L. present an annual address, developing some topic of interest to all of his clientele. The committee approves the suggestion with the understanding that the address should represent original thought on some vital issue, that it should not be simply a glorified summary of the minutes of business meetings, important as these meetings are, and that it should be open to other librarians.

\section{Encourage study and research by librarians.}

There is a fine intellectual ferment in the professional life of college, university, and research libraries today. In our professional literature, on the floor of conferences, in the management of libraries, we meet an attitude of critical inquiry, a willingness to experiment with ideashowever new-that offer real promise of improvement. The A.C.R.L. should assist in diffusing this spirit in every way possible. Its conference programs should reflect, not hasty preparation, but the results of patient study and careful investigation. This means that programs on a whole should be better conceived, and that more time should be allowed those who participate to work through the prob- lems assigned them. These programs should also provide a forum for the presentation of results of significant studies of wide interest to librarians. While the programs of the A.C.R.L. will thus be enriched by planned effort to promote study and research, more than the annual and midwinter programs are involved. The A.C.R.L. should take advantage of the best research abilities in the profession in developing its program of activities. The important thing is full utilization of intelligence in the solution of our problems, and to such a form of progress, librarians are by circumstance of their calling dedicated.

Library problems will naturally be the subject of most of the study and research sponsored by the A.C.R.L.; but it should be emphasized that the committee, while recognizing fully the importance of these problems, is also looking beyond them to something that is antecedent to their solution. In encouraging study and research, we must, in other words, encourage the development of what for lack of a better term we may call research power-the capacity for penetrating analysis, the attitude of impartiality, the habit of reflective judgment, which are among the products and evidences of disciplined intelligence. In developing such power on library staffs, no subject limitations need be imposed, although some subjects are closer to the center of professional interest than others. The extent to which scholarly interests within a staff can be encouraged will of course vary from one library to another. This is not a misguided plea for libraries to attempt the impossible; books still have to be charged and discharged, windows still have to be raised and lowered; but it is a plea for more attention on the part of the profession to the gifted librarian 
who demonstrates his ability to earn scholarly recognition.

\section{Initiate publication.}

Two classes of publication require the attention of the A.C.R.L. One class includes publications which are as a rule conceived by librarians and are published largely for libraries or librarians. One example is the Union List of Serials; another the second Shaw supplement now under discussion. The publications of the last quarter of a century have included a steadily increasing number of works in this class-some of them expensive, some of them inexpensive. Alongside these works have been appearing others which, whoever the author or publisher, have been aimed primarily at the library market. Examples of such extensive works of reference are the Dictionary of American Biography and Biological Abstracts. As private libraries decrease in importance and as increasing dependence is placed on institutional libraries, the library market will doubtless move even further from the periphery to the center of attention. If we are to avoid poor coordination and a certain amount of exploitation in the publication of works intended for libraries, the A.L.A. may need to consider expanding its publishing program. The Association of College and Reference Libraries should lend assistance, even if it means having a sort of $\mathrm{H}$. W. Wilson Company, i.e., an agency publishing a wide range of books aimed at reaching the library market-under A.L.A. control.

9. Sponsor a program of activities in behalf of college, university, and research libraries.

This program will be shaped from time to time by the Board of Directors. The following is not an outline of a fullfledged program of activities but rather a brief statement of aims that should be embodied in such a program.

a. Further the educational uses of libraries. College libraries have too often operated as adjuncts rather than as implements to the instruction program. The situation is improving. The better colleges have made noteworthy progress in the productive use of their libraries. In most of our colleges, however, there is still room for improvement and librarians should assist their colleagues in making of their libraries the most effective implements possible. It should not be necessary for us to leave the initiative in developing significant activities in this field to other national organizations.

b. Broaden the basis of cooperation among libraries. Cooperation among libraries serving higher education cannot be considered purely from the standpoint of library policy alone. Two libraries cannot cooperate very fruitfully if the institutions they serve are competing with each other in every field of endeavor in which they can get students. The present duplication of educational effort-sometimes a needless and wasteful duplication-limits the effectiveness of library cooperation and is likely to continue to limit it for some time to come. In the meantime, opportunities for cooperation are not wanting and should be utilized. We have not yet exhausted the possibilities of exchanges, although some indeed are a bit weary of the subject. A recent Carnegie experiment suggests advantages of cooperative buying which the individualistic traditions of American colleges should not prevent us from exploring. A visitor from Mars would possibly question, upon discovering so many copies of the same title being 
cataloged by so many different catalogers in different libraries at about the same time, whether we have exercised the most brilliant imagination in perfecting centralized cataloging. A Division of $\mathrm{Li}$ brary Cooperation at the Library of Congress, recently announced, will presumably provide leadership in dealing with this and numerous other library problems. Other agencies which can be expected to assist in dealing with matters of common interest include the A.L.A. Board on Resources and the Library Division of the Office of Education. The Association of College and Reference Libraries should work closely with all of these agencies in an endeavor to promote cooperation and thereby to strengthen the resources and improve the services of American libraries.

c. Aid the scholar. In a letter to the committee, one librarian deplores the "unfortunate divorce between scholarship and its demands and the librarians of most of the colleges. It is only here and there that I have encountered a college librarian or a junior college librarian who seems to grasp the point of view of college faculties." This observer notes the disposition on the part of far too many libraries to confine their interests "more closely to technical processes than to the use of books entrusted to their care." The viewpoint here expressed is essentially the same as that found in another letter, in which it was stated that the development of a program of research and publication in the field of college, university, and research libraries which will enable these institutions more effectively to play their important role in higher education "calls for a college and university library personnel of a high order . . ." 5 These

s Wilson, Louis R. "The Challenge of the I930's to the 1940's." College and Research Libraries $\mathrm{I}: 3 \mathrm{I}$, Mar. 1940. comments raise questions about recruiting and training for librarianship which are all the more pointed in view of the number of prominent posts which have recently drawn gifted men from outside the ranks of trained librarians. This trend does not seem to be especially difficult to understand. It is an expression of an insistent claim that the scholar is entitled to understanding aid from his library. The injured cries of a disappointed profession will not modify that claim. Its implications should be carefully studied by the Association of College and Reference Libraries in making plans for the service to be given by it and by our libraries.

d. Cultivate international understanding. Meeting in one of the twilight hours of history, we cannot pretend to see very clearly the full meaning of all that has been taking place. But we are agreed that our world has been rather sadly out of joint of late. On the one hand, we have seen national interests cultivated with an intensity bordering on the fanatical, while on the other hand, learning has made national boundaries for literate men of goodwill progressively artificial. Searching among the uncertainties of these times for solid principles on which to build the good society, librarians place a good deal of faith in cultivating international understanding. It is a principle which, for the time being, will perhaps not find very wide application outside our own hemisphere, but it should not be overlooked by the A.C.R.L., now or later, in planning its activity program. Our libraries should continue to be reflections of the international character of scholarship, and should therefore aid in overcoming the barriers to mutual understanding imposed by language, distance, and interests that are purely national. 
Io. Support College and Research Libraries.

Members of the A.C.R.L. have supported their new journal loyally from the beginning. They have subscribed for it personally, they have written substantial articles for it, they have promoted it energetically. We must not flag nor fail as the novelty of the undertaking wears off. The journal is needed. Only time, editorial vigilance, and experimentation will define its place and character, but its general purpose is clear. It is not primarily a current bibliography or an organ for book reviews but a medium for expression and communication. In it should be found the results of the best thought in the library world and in the learned world as thought there relates to libraries. As the official organ of the A.C.R.L., College and Research Libraries should be put on a sound basis of financial support, its articles should be selected on the basis of merit, and it should be committed to no policy except the furtherance of the interests, broadly conceived, of college and research libraries.
Mabel Conat
Margie Helm
B. Lamar Johnson
Evelyn Steel Little
Clara Van Sant
Carl M. White, Chairman

\section{Checklist of Short-Title Catalog Books}

Continued cooperation from librarians and bibliographers is earnestly solicited by William W. Bishop, librarian emeritus, University of Michigan, in checking the Preliminary Checklist of Copies in American Libraries of ShortTitle Catalogue Books. It is necessary that holdings be reported accurately and it is hoped that additional checking will reveal copies not yet located in any American library.

The checklist is the result of an effort to locate in this country copies of books listed in the Short-Title Catalogue for the purpose of filming the title pages, colophons (if any), and tables of contents. "For several years," Dr. Bishop says in the Preface to the Preliminary Checklist, "a group of American scholars interested in the English Renaissance has been considering ways and means for providing more effective clues to the contents of books published in Great Britain in the fifteenth, sixteenth, and early seventeenth centuries." The original plan was to do the filming in England, but the outbreak of the war rendered this plan impossible, hence the shift to American resources.

The response to this project has been encouraging and Dr. Bishop reports that he has already received notes of a considerable number of books previously not known to be in an American library. All libraries owning a considerable collection of British printing before $\mathrm{I} 64 \mathrm{I}$, whose holdings have not been checked, are urged to write to Dr. Bishop for a copy of the Preliminary Checklist. 